Published by: Singapore Economic Review, https://doi.org/10.1142/S0217590819500413

\title{
ASEAN electricity market integration: how can Belt and Road Initiative bring new life to it?
}

Lixia Yao, Philip Andrews-Speed and Xunpeng Shi

\begin{abstract}
This paper assesses how China's Belt and Road Initiative (BRI) can bring investment and technology into ASEAN and its impact on ASEAN's electricity market. With the theoretical framework of scenario analysis, this paper provides three scenarios for ASEAN electricity market integration: the Lao PDRThailand-Malaysia-Singapore (LTMS) arrangement, a power exchange between heterogeneous grids in the GMS region, and a fully competitive electricity market with a fully-developed ASEAN Power Grid (APG). Based on these scenarios, the paper examines the extent to which the BRI can assist electricity market integration in the ASEAN region. It is found that BRI can best fit with and facilitate the first scenario. Given the uncertain outlook for the electricity market integration in the GMS region, how China's BRI can play a role in facilitating the GMS electricity market integration is not clear under the second scenario. Further, BRI may be less helpful in the third scenario in which the region's master plan of APG would be realized. In any sense, how BRI can fit with and facilitate ASEAN's electricity market integration would more depend on the host countries rather than the Chinese side.
\end{abstract}

Key words: ASEAN; Belt and Road Initiative; electricity market integration 


\section{Introduction}

The Association of Southeast Asian States (ASEAN) has a long established plan to connect the national grids of its member states and create an ASEAN power grid (APG). Currently the interconnection of grids are mostly in the continental Southeast Asia and the electricity trading still remains bilateral and the realization of the ambitious plan needs significant amount of investment in the electricity sector. More recently, ASEAN has announced the intention to promote multilateral power trading and develop an integrated regional power market.

Against this backdrop, China has emerged as a major investor in the region's electricity industry. China indeed has a long history of investing in ASEAN's energy sector, but since the 2000s Chinese energy companies have been increasingly active in this region. They have been building coal-fired power plants and hydroelectric dams, and have invested in renewables energy. With regard to Chinese investment in energy connectivity infrastructure, China appears to be very interested in building transmission lines in its neighboring countries so that these lines can be connected with those in China. Therefore, China-built lines are mainly located in mainland Southeast Asia, in Laos, Vietnam, Myanmar and Cambodia.

Since the launch of China's Belt and Road Initiative (BRI), Chinese investment in Southeast Asia has increased. Chinese companies have been particularly active building coal-fired power plants in Indonesia, in direct response to the government's ambitious plans to boost the nation's generating capacity as fast as possible. China continues to be active in hydropower construction in the Greater Mekong Sub-region (GMS) (Lu 2016). It is also building solar and wind farms and manufacturing facilities for solar panels in Southeast Asia, although the scale is small compared to its investment in the hydropower sector. One BRI power grid project has also been put into operation: the so called 'first Belt \& Road power grid cooperation project' in Laos, which is also connected to power grids in Southern China (Xinhua 2015).

The aim of this paper is to examine the extent to which the BRI can assist electricity market integration in the ASEAN region. Using the framework of scenario analysis, this study presents three scenarios of electricity market integration in ASEAN and assesses how China's BRI might fit with each scenario. The three scenarios are: the Lao PDR-Thailand-Malaysia-Singapore (LTMS) arrangement, a power exchange between heterogeneous grids, and a fully competitive electricity market with a fullydeveloped ASEAN Power Grid. It is found that BRI can best fit with and facilitate the first scenario. Chinese companies, with their existing investments in the power sector in the continental Southeast Asian countries such as Laos and Thailand, can provide indirect support to this scenario; and probably direct support when further down investments in Malaysia and Singapore are made. Yet given the uncertain outlook for the electricity market integration in the GMS region, how China's BRI can play a role in facilitating the GMS electricity market integration is not clear under the second scenario. Further, BRI may be less helpful in the third scenario in which the region's master plan of ASEAN Power Grid would be realized. In any sense, how BRI can fit with and facilitate ASEAN's electricity market integration would more depend on the host countries rather than the Chinese side.

This paper is structured as the following: section 2 reviews energy situation and the political economy of energy market integration in ASEAN; section 3 establishes the analytic framework of scenario analysis with a discussion of the rationale for scenario analysis of ASEAN's electricity market integration; section 4 discusses in detail the current electricity market in ASEAN and each of the three 
scenarios of its market integration; section 5 discusses how China's BRI can fit with each scenario; and section 6 concludes the paper.

\section{The context of electricity market integration in ASEAN}

Energy market integration cannot be viewed in isolation from the broader political economy of ASEAN integration. This section reviews the energy situation of ASEAN and examines the political economy of energy market integration in ASEAN in order to build a better understanding of different scenarios of electricity market integration in this region which is discussed in the subsequent sections.

\subsection{Energy Situation in ASEAN}

The ten ASEAN member states are at different stages in their economic development, yet most of them have rapid economic growth and are experiencing significant increase in energy demand. Between 2000 and 2016, they collectively experienced economic growth of more than 125 per cent, reaching a combined GDP of US\$7.4 trillion in 2016 (in purchasing power parity terms) (OECD/IEA 2017, 34). That year, total primary energy demand in ASEAN reached 643 Mtoe, of which fossil fuel accounted for 74 per cent (OECD/IEA 2017). Figure 1 illustrates the fuel mix in ASEAN in 2016.

Figure 1: Fuel mix in ASEAN, 2016

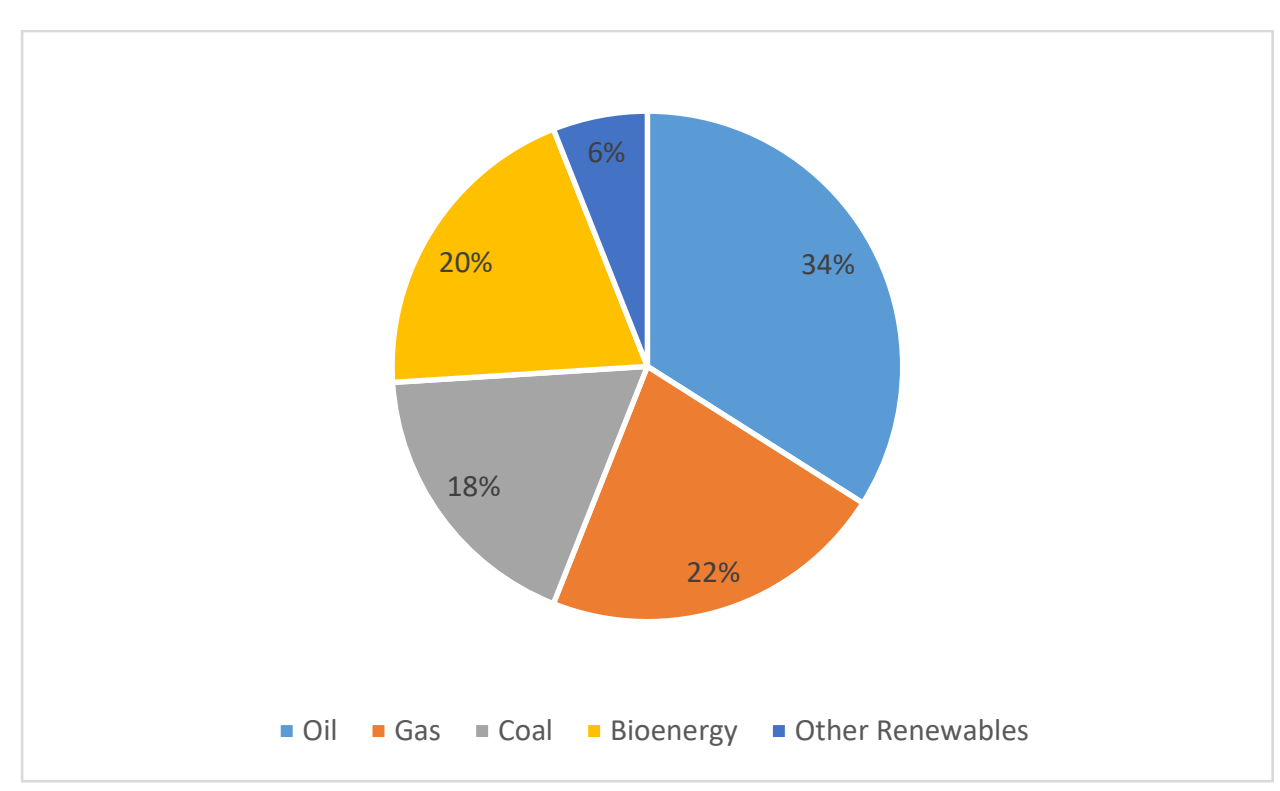

Source: OECD/IEA (2017).

In terms of electricity supply, ASEAN's installed power generation capacity more than doubled over the same period, reaching around 240 gigawatts in 2016. Fossil fuels continue to dominate the power generation mix. There has been a rapid rise of coal-fired power capacity, although the growth has been slowing down since 2014. The capacity of renewables-based electricity has tripled since 2000, with a rapid expansion of hydropower. In 2016, non-hydro renewables accounted for 6.5 per cent of the total installed electricity capacity. Bioenergy and geothermal capacity contributed to about 70 per cent of the non-hydro renewables (OECD/IEA 2017, 23). Figure 2 shows the power generation mix in Southeast Asia in 2016.

Figure 2: Power generation mix in ASEAN, 2016 


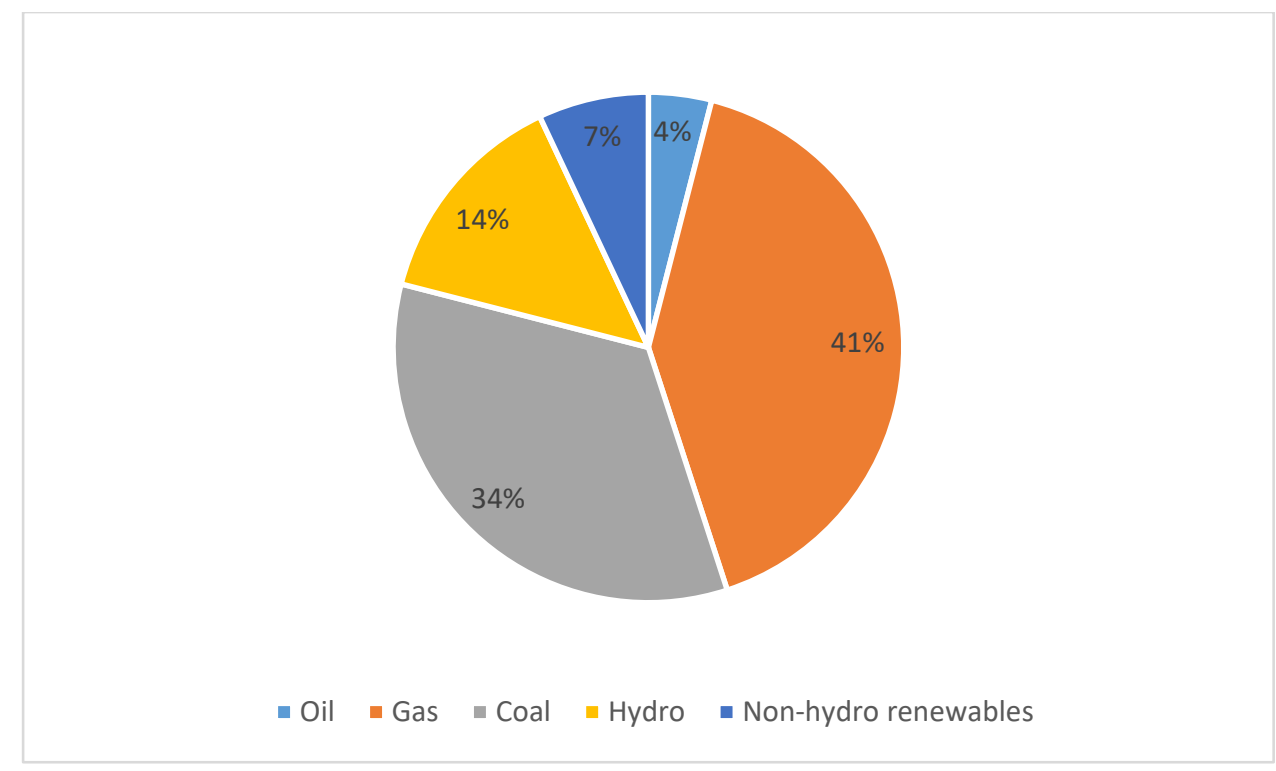

Source: OECD/IEA (2017).

Besides increasing electricity capacity, ASEAN has also been putting efforts to expanding power connectivity. Linkage of power grids across countries has long been pursued. Adopted in 1997 at the $2^{\text {nd }}$ ASEAN Informal Summit, the ASEAN 2020 Vision envisioned an energy-interconnected Southeast Asia through two major energy projects: the ASEAN Power Grid (APG) and the Trans-ASEAN Gas Pipeline (TAGP). The APG was proposed for the aim of sharing resources and promoting the efficient utilization of electricity. Through power trading, APG has also been expected to promote a win-win economic relationship between the countries (APAEC 2004). Therefore, APG is one of the most important elements for electricity market integration in ASEAN. The benefits of an integrated ASEAN electricity market are obvious. Trans-border power grid interconnections and market integration can relieve burdens related to excess power generation capacity, alleviate poverty, reduce energy prices, mitigate supply shortages, and promote development of clean energy and sustainability. Further, economic analysis has identified more benefits such as significant net economic savings via development of cheaper renewable energy resources (Silitonga 2018).

\subsection{The political economy of electricity market integration in ASEAN}

An applicable approach to understanding the political economy of energy market integration of Southeast Asia is offered by the 'Murdoch school', which posits that institutional outcomes (e.g., energy market integration) are inherently determined by rival actors that consistently compete for power and resources (Jones 2016). Against this backdrop, the member states that demonstrate more enthusiasm for further integration may need to take a proactive approach in understanding the difficulties faced by other member states that are hesitant at best and resistant at worst. Since the benefits accruing from a fully integrated energy market will only be realized in the long term, some member states seem to discount their potential gains right now. This impacts the political will of each member state to act urgently. In any sense, as Andrews-Speed and Hezri (2013) pointed out, the operation of a regional energy grid requires a high degree of collective action, which is likely to require delegation of sovereignty of the participating countries. ASEAN, a region with ten diversified member states, may be in a complex situation in this regard. 
To address the complexities of the underlying political economy, there is a need for clarity on the decision-making mechanism with regard to energy market integration. This pertains to who will make decisions, and how such power will be distributed across different members in this regard. For instance, Nordic energy cooperation relies on consensus among its members (Joergensen 2016). Thus the Nordic power market, 'Nordpool', developed slowly, starting with bilateral exchange between Norway and Sweden, grew to include Denmark and Finland, and eventually integrated with the European Union market (Bredersen and Nilsen 2013). There is also a need for unambiguous clarity among members as to what kind of public good is aspired to be created, and what benefits are expected to be achieved (Andrews-Speed 2011). Matters related to benefits and costs cannot have national basis only, as it potentially affects the wellbeing of millions of people living in the member states. Again, as ASEAN member states are quite diverse in terms of economic development, political system, and natural resource endowment, it can be even more difficult for them agree on the benefits, costs and people's wellbeing of an integrated energy market.

Further, trust is an important requirement for collective action and a prerequisite for a high level of energy market integration. However, a lack of political trust is a prominent obstacle that hinders collective action in the ASEAN region. The reasons lie in its history. Most ASEAN member states are young nations that emerged from colonial rule and the Second World War in weak condition. This makes them very sensitive about sovereignty (Andrews-Speed and Len, date). To make matters worse, factors such as unresolved disputes over land borders and maritime demarcation and ethnic unrest in border areas make the ASEAN countries tend to look at each other with suspicion. For example, there has still been disputes on the border issue between Vietnam and Cambodia. Their border disputes had led the Vietnamese to invade Cambodia in the late 1970s. Today still little progress on boundary agreements have been made between the two countries. Further, as one of the most ethnically diverse regions in the world, ethnic unrest frequently happens in the region. In Myanmar, for instance, the escalation of conflict in Kachin state between the army and the Kachin Independence Organisation (KIO) highlights the ethnic issues in the country. The violence has mainly centred on the control of natural resources such as amber mines, jade mines and hydropower plants (Hart 2018). This can make the investment in Myanmar a complicated issue.

Besides the above obstacles that may hinder the integration of energy markets, some other challenges particularly impede the development of an integrated electricity market in ASEAN, such as the technical, economic, and institutional and market structure challenges and energy security concerns of member states. First, the technical challenge is a major obstacle for the multilateral connections needed to create an ASEAN Power Grid (APG). The power systems of ASEAN member states have different technical standards and their transmission lines may also have different voltages. The existing power grid interconnections serve as a bad example that hinders the progress of the APG. For example, most of the electricity exported from the Greater Mekong Sub-region (GMS) member states is from generating plants that are independent of the national grids. These electricity transmission lines are built exclusively for exporting electricity, and these electricity flows are small and unidirectional. However, if a large interconnected system is to be developed, it is necessary to coordinate the technical standards and align the standards for electricity-exporting grids with the standards of domestic grids that had not been designed specifically for exports of electricity (Shi and Malik 2013). To put it simply, harmonization of some technical standard codes is a prerequisite for APG development. 
Second, investment constitutes a key uncertainty in the expansion of interconnected power grids across ASEAN. Since the early 2000s, average annual investment in power plants more than doubled, while the average annual investment in transmission and distribution systems remained almost flat (IEA 2015). Financing cross-border transmission lines will require substantial investment yet it is unclear where the funding is going to come from. Since 2000, about US\$365 billion has been invested in the power sector across ASEAN, of which about US\$195 billion went to grid expansion and improvement. However, it is estimated that ASEAN would need about US\$ 690 billion invested in its transmission and distribution sectors by 2040 (IEA 2017). Completion of some interconnections is more realistic than others thanks to the existing funding from development banks and private sector. Yet there is uncertainty about the future of some other interconnections due to lack of funding, although their benefit to the region is undeniable (Finenko, Owen and Tao 2017).

Another major constraint for APG development is that many interconnection projects are not yet commercially viable which makes it difficult to secure financing (Shi and Malik, 2013). The prevailing subsidies in many ASEAN countries not only discourage investment in clean energy, fossil fuel exploration, and infrastructure, but also prevent greater integration of regional energy markets (Shi and Kimura, 2013). The removal of subsidies, however, is politically challenging, as has been the case of Malaysia (Li et al., 2017). The predominance of 25-year power purchase agreements (PPAs) in the governance of most of the interconnections, is a further commercial factor that prevents the development of multilateral power trading (Antikainen et al., 2011).

Third, institutional challenges further complicate the situation and different modes of power sector regulation can bring about further obstacles. Of the ten ASEAN member states, only Singapore has a fully liberalized electricity market. Among ASEAN countries, the Philippines comes second to Singapore in terms of having single buyer pools in certain parts of the electricity network. Malaysia and Thailand both have IPPs but they do not have single buyer pools. Other countries such as Cambodia, Myanmar and Laos are served by vertically-integrated state-owned utilities. Price control mechanisms and electricity subsidies in several ASEAN countries are also potential obstacles to the APG development and electricity market integration in ASEAN (Sahid, et al. 2013). Another regulatory obstacle is different degrees of liberalization in the transmission sector. For example, private companies in Indonesia are allowed to construct transmission lines, whereas in Malaysia, only the state-owned utility company can build transmission lines (Shi and Malik 2013). As a result, electricity trading has a lengthy approval process due to the different nature of the leading companies of both countries in the market. Consequently, the harmonisation of regulatory systems will need a lengthy developmental process.

Finally, the prevailing nationally-focused energy security paradigm of ASEAN member states lies behind the continuing fragmentation of the energy markets because the traditional national energy security concept requires maximising self-sufficiency which undermines potential for regional energy trade (Shi and Kimura, 2010; Wu et al., 2013). In addition, some countries may limit their dependence on other countries to protect their electricity utilities. These energy sector concerns will reduce the electricity trading opportunities (Shi and Malik 2013). Countries will have to balance the trade-offs between possibly cheaper and cleaner electricity from overseas and national security. If a country becomes reliant on electricity exports, it faces the risk of electricity supply interruption by the exporter. Interruption can be intentional or unintentional. For example, if there is a drought in a big exporting 
country that relies on hydropower generation, such as Laos, the reliance on such an exporter may also cause serious problem for the importing country.

Further energy market integration will need to be based on projection of different possible forms of integration that may affect the energy market of the individual member state and the region as a whole. To look into the trajectories of energy market integration, this study adopts scenario analysis, focusing on the projection of ASEAN's electricity market integration. Scenario analysis has been developed since the 1960 s to produce extrapolations that predict the future. The next section discusses the framework of scenario analysis that is applied to electricity market in ASEAN.

\section{The framework for understanding market integration: scenario analysis}

Since the 1960s, more sophisticated forecasting techniques which can produce extrapolations to predict the future have been developed. One of these techniques is the scenario analysis. Scenario analysis is a powerful tool to react to future conditions and to develop strategies to address such conditions. Scenarios provide a long-term macro view which serves as a backdrop for more traditional forecasting approaches. The methodology of scenario analysis has been extensively used for policy analysis, social forecasting, and decision making in 1960s. In the late 1980s, it matured as a welldeveloped planning and forecasting technique. Scenario analysis provides a powerful tool to react to future conditions and to develop strategies to address such conditions. This methodology is best in use when scenarios are suited in "long-term, macro, uncertain environments which are typified by a scarcity of data and a large number of non-quantifiable factors" (Huss 1988, 380). In this section, we review the state of the art associated with scenario analysis and provide the rationale for scenario analysis in electricity market integration in ASEAN.

\subsection{State of the art of scenario analysis}

Scenarios provide a long-term macro view which serves as a backdrop for more traditional forecasting approaches. The methodology of scenario analysis has been extensively used for policy analysis, social forecasting, and decision making in 1960s. Helping the decision-makers to be prepared for the future, scenario analysis deals with uncertainty and the usefulness of overall decision-making process (Heijden 2005; Varum and Melo 2010).

It provides an overall picture of the future and highlights the interactions among several trends and events in the future (Martino 2003). Moreover, it integrates all complex elements to describe a future situation and the course of events which allows the decision-makers to move forward from the actual to the future situation. Therefore, scenario analysis is considered a valuable tool that helps decisionmakers to prepare for possible eventualities. Until now the most popular definition of scenario is that scenarios are alternative futures resulting from a combination of trends and of the policies of agents (Fontela and Hingel 1993, 139). ${ }^{1}$

On different basis, scenarios can be classified into different types. They can be grouped and classified on the basis of topic, perspective (Porter, et al. 2011), scope, focus of action, level of aggregation (Mietzner and Reger 2005), and methods of building (van Notten, et al. 2003). Particularly, perspective and methods of building are most relevant to the study in this paper. On the basis of perspective,

\footnotetext{
${ }^{1}$ For a comprehensive literature review of scenario analysis, see Amer, Daim and Jetter (2013).
} 
scenarios can be classified into descriptive and normative scenarios. According to Porter, et al. (2011), descriptive scenarios are extrapolative in nature and present a range of events that describe alternative futures whereas normative scenarios are goal-directed and passively react to policy planning concerns for the achievement of desired targets. On the basis of methods of building, scenarios can be qualitative and quantitative. Georgoff and Murdick (1986) published a paper in Harvard Business Review that explicitly specifies scenario analysis as a qualitative technique designed as "smoothly unfolding narratives that describe an assumed future expressed through a sequence of time frames or snapshots" (p. 114), while as of the past decade, many have been making extensive use of quantitative tool and techniques (Vecchiato and Roveda 2010). This study adopts the descriptive scenario with a qualitative technique to forecast the future of electricity market in Southeast Asia.

\subsection{Rationale for scenario analysis in electricity market integration in ASEAN}

Despite of these perceived benefits, the progress of ASEAN electricity market integration still remains slow given the obstacles discussed in section 2. These obstacles are difficult to overcome. Of all the obstacles, the technical incompatibility of transmission lines between some ASEAN countries need to be addressed before other problems can be solved. Further, technically if connected, the unstable voltage and frequent power outages in some poorest countries in the region such as Cambodia, Laos and Myanmar can seriously affect the overall performance of the regional power grid (Zhang and Zha 2014). Political distrust between some of the ASEAN countries involved in the integration can hinder the interconnection of power grids across their borders (Shi and Kimura, 2013; Wu et al., 2012). As a result, some governments would boost their own electricity capacity rather than save costs by connecting to their neighbors' grids (Olchondra 2016) while some other governments are less keen to support APG due to the need to protect their own energy sectors (Kumar 2015).

National energy market regulations have delayed the development of APG as well. Electricity is often the most regulated energy product of a country. To break up monopolies and attract investment, electricity sector liberalization has been implemented across ASEAN to varying degrees since the 1980s. Many targets, however, have not been achieved yet (Sharma 2005). Regulation gaps of mismatches have impeded cross-border power trading, including issues such as taxation, transmission tariffs, and third-party access (Andrews-Speed 2016). Another major obstacle is the lack of capital. The investment requirement of eventual realization of APG is estimated to be US\$5.9 billion (Zhang and Zha 2014, 92). However, as Andrews-Speed (2016) mentioned, "[n]ational governments and stateowned enterprises have been unable, unwilling or slow to invest and, at the same time, many interconnection projects remain commercially unattractive to private investors" (p. 11).

The difficulty of removing these obstacles produces a lot of uncertainties for the evolving of APG and electricity market integration. With this said, our study evaluates what are the likely trajectories of the evolving electricity market integration. For such evaluation, scenarios offer a powerful approach to glimpsing into the future. The following section constructs three scenarios for ASEAN electricity market integration. 


\section{Scenarios for ASEAN electricity market integration}

This section reviews the current situation of ASEAN power grid connection and forecasts the ASEAN electricity market integration scenarios.

\subsection{Current situation of ASEAN power grid connectivity}

Linkage of power grids across countries has long been pursued in ASEAN. Adopted in 1997 at the $2^{\text {nd }}$ ASEAN Informal Summit, the ASEAN 2020 Vision proposed an energy-interconnected Southeast Asia through two major energy projects: the ASEAN Power Grid (APG) and the Trans-ASEAN Gas Pipeline (TAGP). The APG was proposed for the aim of sharing resources and promoting the efficient utilization of electricity (ASEAN, 2008; Shi, 2014). Through power trading, the APG has also been expected to promote a win-win economic relationship between the countries. Therefore, APG is one of the most important elements for electricity market integration in ASEAN. Yet the development of APG has encountered technical, political, institutional, and financial obstacles. These factors, among others, also affect ASEAN electricity market integration (Halawa et al., 2018; Shi, 2014). Nevertheless, the basic foundation and also the most important prerequisite is the physical cross-border interconnection of national power grids across ASEAN. ASEAN has been endeavoring to construct the ASEAN Power Grid (APG) since 1997 when HAPUA (Heads of ASEAN Power Utilities/Authorities) was tasked to ensure regional energy security by sharing energy resources via APG (ACE 2017a). Currently, there are totally 16 planned APG projects, 8 of which have been completed. APG is still at the stage of physical interconnection development between individual member states (ACE 2017b, 9). However, even if all these interconnections are realized as planned, APG does not by itself bring about an integrated ASEAN electricity market (Shi, 2014; Shi and Malik, 2013).

\subsection{ASEAN electricity market integration scenarios}

Nonetheless, the integration of the market has to start in a gradual and incremental way, and the bottom-up approach is more suitable for ASEAN than the top-down one. ASEAN does not have any institution that represents a strong supranational authority, nor does it have an overall regional governance to facilitate the development of regional power connectivity. Therefore, a bottom-up and incremental approach is practical to advance regional power connectivity in the absence of an overall regional integration architecture. In order to pursue the APG programme, HAPUA adopted a strategy that encourages the gradual development of the identified interconnection projects. First on crossborder bilateral terms, then gradually expanding to a sub-regional basis and finally to a totally integrated Southeast Asian power grid system (Shi and Malik 2013). This sub-section constructs three scenarios of ASEAN electricity market integration with a discussion of how China's BRI can play a role under each scenario.

\section{Scenario 1: Lao PDR-Thailand-Malaysia-Singapore (LTMS) Interconnection}

Currently all power trading within ASEAN is bilateral between individual member states. ASEAN is yet to develop its first multilateral connection so as to initiate multilateral electricity trade by 2018 . Using existing interconnections, the pilot project 'Lao PDR-Thailand-Malaysia-Singapore (LTMS) Power Integration Project (PIP)' was intended to start multilateral electricity trade from Laos to Singapore, through Malaysia and Thailand. This pilot project was expected to be a pathfinder to realise multilateral electricity trade in the ASEAN (ACE 2017b). Under the first phase of the LTMS Project, 100 MW of electrical power would be delivered to Malaysia via Thailand's national grid by 1 August 
2018. Under the second phase, it is expected that Laos will export another $100 \mathrm{MW}$ of power to Singapore via Thailand and Malaysia's network by 2020 (Lao News Agency 2017; The Laotian Times 2017). However, the involvement of Singapore is more complex on account of the specific context of its power sector. In principle, the availability of hydropower from Laos would diversify Singapore's fuel mix, enhance security of supply and reduce carbon emissions. However, Singapore not only hosts the only fully liberalized power market in ASEAN, but this market has massive generation overcapacity. If the power available via LTMS was truly competitive in this market, the existing generating companies might be driven out of business. Conversely, if the transmission tariffs charged by Thailand and Malaysia were high, the power from Laos would not be able to enter the Singapore market without special dispensation. Therefore, Singapore has withdrawn from the LTMS project for the moment.

From the perspective of energy security concerns, Malaysia and Thailand have the motivation to meet their rapidly growing electricity demand without increasing their dependence on natural gas imports for power generation. On the exporter side, Laos is keen to be the battery of Southeast Asia. It has large hydropower potential and it expects to operate 100 hydropower plants with combined installed generation capacity of 28 GW by 2020 (Phomnuny 2017).

Scenario 2: Multilateral power exchange

Although ASEAN has already established some institutions to develop APG, such as ASEAN Centre for Energy (ACE) and Heads of ASEAN Power Utilities/Authorities (HAPUA), none of them have binding authority. There is still a long way to go before ASEAN can uniformly make rules to create a truly competitive ASEAN-wide electricity market due to the big differences in the national conditions of the individual countries. Therefore, at the current stage, due to technical, regulatory and other barriers, it may only be possible initially to create a multilateral power exchange platform involving willing participants. But as more countries join and as market actors realise the advantage of trading power, investment in interconnection will grow and the sophistication of trading mechanisms will increase. That is to say, to first establish the market can bring in investment and expansion of power grids. Such an approach was taken by the Nordic countries in developing the Nordpool and is currently being pursued in other regions, notably in the Southern African Power Pool (Bredesen and Nilsen 2013).

The Greater Mekong Sub-region (GMS) could be a good place to test such an exchange due to the relatively high level of interconnection. Currently electricity trade in GMS is only conducted through PPAs between utilities. The ideal condition of the electricity market integration in the region would be the establishment of a regional electricity exchange center with multiple buyers and sellers within the GMS countries that could then expand across the rest of ASEAN. Countries with huge hydropower potential such as Laos, Myanmar and Cambodia can be electricity exporters while countries with large electricity demand such as Thailand, Malaysia and Vietnam would be the importers. Under such scenario, according to a study done by ADB (2009), Thailand would be the dominant importer of electricity, which primarily comes from Myanmar through Laos. Located in the center of the continental Southeast Asia, Thailand can be a trading hub of electricity.

The GMS power market integration was planned to be progressed into several stages from bilateral cross-border connection and grid-to-grid power trading between any pair of GMS countries to transmission links for cross-border trading using third party's transmission facilities and a fully integrated GMS regional competitive power market. GMS countries are now moving from the stage 
of bilateral electricity trading to trading between any pair of GMS countries with access to third country's transmission facilities (ADB 2018).

Scenario 3: A fully competitive electricity market with a fully-developed APG

Under this scenario, there will be comprehensive regulatory, institutional and market arrangements based on the ASEAN countries' high-level cooperation and trust. This scenario, a fully-developed APG, is a major energy infrastructure project mandated in 1997 by the ASEAN Heads of States/Governments under the ASEAN Vision 2020. Motivations for a full APG are to complement different load shape among ASEAN countries and to make ASEAN less dependent on fuel imports from non-ASEAN countries. Further, energy resources sharing and potential total cost savings from interconnection are beneficial to the ASEAN region as well (Shi and Malik 2013). The ultimate goal of APG is to interconnect the grids of all the 10 ASEAN member states to optimize the use of energy resources in the region by sharing the benefits and to reduce capital required for the expansion of generation capacity. In such a fully competitive power market, there will be vertical unbundling of state-owned utilities. There will also be full independence of transmission system operators from electricity production. More importantly, a fully competitive power market has unrestricted and non-discriminatory third-party grid access to all participants (Finenko, Owen and Tao 2017), which would be one of the key characteristics in the fully competitive power market. Against this condition, comprehensive institutional arrangement including summits, ministerial meetings and senior official meetings are needed.

\section{The role of BRI under ASEAN electricity market integration}

With these scenarios in mind, this section discusses how China's BRI can bring new source of technology and funding to the electricity market integration of ASEAN under each scenario.

\subsection{BRI under scenario 1}

We find that of the three scenarios, BRI can play the most important role under scenario 1 , the LTMS interconnection. China has long invested in the power sector in the continental Southeast Asia. These investments are in projects that increase power capacity or expand power connectivity within the borders of the host country. In its neighboring countries Laos, Vietnam and Myanmar, Chinese companies have also built national power transmission lines that can be connected to China's power grid to enable electricity trading. Although these connections operate on a bilateral basis, they are beneficial to the power grid building of these continental Southeast Asian countries. Since BRI was initiated, one 'BRI power grid project' has been put into operation - the 'first Belt \& Road power grid cooperation project' located in Laos. Constructed by China Southern Power Grid, this power grid project links four northern Lao provinces and is supposed to enhance regional connectivity (Xinhuanet 2015). It seems that Chinese companies are very interested in constructing transmission lines that connect China with its neighboring countries such as Laos and Myanmar, which are also willing to exchange electricity with China. By the year 2035, it is hoped that the power grid system in some of these continental Southeast Asian countries could be connected to China's power grid through bilateral, multilateral and regional arrangements (GEIDCO 2018).

It is also planned that a synchronous power interconnection will be established within Southern China, Laos, Myanmar, and Thailand. Currently, in terms of voltage level, only 7 of the existing cross-border 
transmission lines (one between China and Myanmar, six between Laos and Thailand) are $500 \mathrm{kV}$. The other transmission lines are $230 \mathrm{kV}, 110 \mathrm{kV}$ and below. By 2035, the power grids in these countries will need to be reinforced. A $500 \mathrm{kV}$ alternating current (AC) synchronous interconnection covering Myanmar, Laos, Thailand and Viet Nam has also been recommended. By 2050, the cross-border power exchange will reach $16 \mathrm{GW}$ between Thailand and Laos. Therefore, further upgrading of the voltage will be required possibly, by deploying ultra-high voltage (UHV) interconnection technology can be used based on the existing 500kV AC synchronization grids (GEIDCO 2018). All these projects will require a large amount of investment and Chinese companies, with their rich experiences in power grid building in the continental Southeast Asian region, would play a key role under this scenario. In addition, there is also an urgent need to construct additional power generation capacity to serve a region with more than 60 million people without access to electricity.

Under the BRI, Chinese companies can invest in countries rich in non-fossil energy resources. They have already been very active in the hydropower sector in Laos and Myanmar. BRI has also brought new opportunities for investment in other forms of renewable power capacity. Chinese companies have already exported some US\$ 8 billion of solar equipment exports from China, making the country the number one exporter of environmental goods and services (Timperley 2018). These continental Southeast Asian countries remain an attractive destination for new and renewable energy investment. For example, Laos' energy sector is dominated by hydropower projects along the Mekong river basin. The Power Construction Corporation of China has been constructing one of the largest hydropower projects in the region with a proposed installed capacity of more than 1,000 MW. Thailand has the highest installed solar capacity in the ASEAN region (IRENA 2017). Since BRI started, Chinese investors have moved rapidly into Thailand's solar power sector to build solar panel factories and solar power projects, making Thailand a country with a fast increasing solar power capacity and a construction centre of solar PV equipment. Malaysia is one of the top three global destinations for renewable energy (BMI Research 2017). With its positive macro-economic outlook and supportive energy policies, it has attracted several Chinese investments especially in solar and hydropower. One key example is the Sarawak Corridor of Renewable Energy, which covers 70,000 sq. km. of the central Sarawak region. From 2008 until 2015, 3.3 per cent of all FDI in Sarawak was from China (Chia and Ten 2015). In 2016, the largest investment in renewables in Malaysia was made by one of the largest Chinese solar manufacturers, LONGi, which is expected to spend about US\$269 million in the country on solar panel manufacturing (Pim 2017).

Chinese companies, with their existing investments in the power sector in the continental Southeast Asian countries such as Laos and Thailand, can provide indirect support to LTMS scenario; and probably direct support to this scenario when further down investments in Malaysia and Singapore are made. Further, through the construction of power generation transmission capacity, Chinese companies, through the BRI, are continuing to contribute to the development of the APG in continental Southeast Asia. If this continues, a foundation will have been built for ASEAN to develop an integrated power market. Nevertheless, progress may still be hampered by some of the political and policy obstacles identified above, in Section 2.

\subsection{BRI under scenario 2}

What Chinese investment can do for ASEAN electricity market integration under scenario 2 is basically the same as described in Scenario 1. Yet under scenario 2, it is needed for the GMS region to get China 
involved in its market integration process. As above mentioned, a $500 \mathrm{kV}$ alternating current (AC) synchronous interconnection covering Myanmar, Laos, Thailand and Vietnam is recommended and therefore synchronous power interconnection could be established throughout Southern China, Laos, Myanmar, Thailand and Vietnam. The GMS region use BRI as an opportunity to realize such interconnection, which is highly possible because Chinese companies have rich experience in power grid construction in these countries.

In addition to the investment in Laos, Thailand and Malaysia, Chinese companies have also constructed power plants and power grids in GMS countries such as Vietnam and Cambodia. In Cambodia, a country not bordering China, Chinese companies such as China National Heavy Machinery Corporation (CHMC) has been very active in the Cambodian electricity market. Together with the Cambodia's state-owned Electricite du Cambodge (EDC), CHMC has committed to constructing the national grid in Cambodia and the renovating of its rural power system. Between 2009 and 2012, CHMC signed several contracts for power grid construction and expansion, including the Phnom Penh Loop Line Transmission System Project, the Cambodian Rural Power Grid Expansion Project (Phase I), and the Phnom Penh-Bavet Transmission Line Project (Industrial Headlines 2016). The Phnom Penh Loop Line Transmission System connects to transmission lines bringing electricity from all over Cambodia, including several hydroelectric dams within the borders of the country and other lines that bring electricity from coal and gas power plants in Vietnam (Chun 2009). The Phnom Penh Loop Line Transmission System not only improves the electricity supply in Phnom Penh but also enhance the supply stability of the entire country. Since the BRI was proposed in 2013, more project contracts have been signed by $\mathrm{CHMC}$ with relevant Cambodian counterparts. Some contracts are follow-up projects of those already existing before the BRI. For example, the Cambodian Rural Power Grid Expansion Project (Phase II, Phase III \& IV) committed in 2014 and the Cambodian Rural Power Grid Expansion Project (Phase V \& VI) committed in 2016 (Industrial Headlines 2016). When completed, these projects will hopefully transmit electricity to each village of Cambodia.

Based on the existing power grids and bilateral power trading, Chinese investment may be positively engaged in and continue to facilitate grid connection within the GMS. Yet how the GMS multi-lateral power trading can bring more transmission lines and how Chinese investment can contribute to GMS electricity market integration remains to be seen. The reason is, under scenario 2, the uncertain outlook for the GMS electricity market integration blurs the prospect of what and how lines will be built. With this said, how the Chinese companies can bring in more lines into this region is also unclear.

\subsection{BRI under scenario 3}

In the third scenario, a competitive electricity market with a fully-developed APG is ASEAN's ambitious plan yet difficult to be realized in the near future. Under this scenario, the fully-established APG will require the establishment of power grid interconnection across Brunei, Indonesia, Malaysia, the Philippines and Singapore (BIMPS), which will consist of three synchronous grids given the geographical condition. They are the Western Malaysia-Singapore-Indonesia (Sumatra-Java), Eastern Malaysia-Brunei-Indonesia (Kalimantan), and the Philippines grids. Given archipelagic nature of this region, there will only be limited power exchange in the near future. Interconnections between these islands have not yet been established and the cross-border electricity trading in Eastern Malaysia, Indonesia and the Philippines will remain relatively small. It is expected that by $2050,400 / 500 \mathrm{kV}$ transmission lines as backbone grids would be constructed in each of the afore-mentioned countries. 
In Indonesia's Sumatra and Java Islands, the voltage level of the existing grid could be upgraded to $1,000 \mathrm{kV}$ considering the land-saving and capacity issues (GEIDCO 2018).

All these grids require huge investment. However, until now it seems that China is more interested in constructing and investing in the lines in continental Southeast Asia. The transmission projects undertaken by Chinese companies are nearly all in the GMS region and bilateral in nature. There is no evidence to suggest that China's BRI would strongly support ASEAN's ambition of region-wide APG or full power market integration. The archipelagic characteristics may hinder not only the integration of the entire ASEAN electricity market, but also the investment interests of Chinese companies. It seems that the BRI may not fit well with this scenario, which requires not only power grids interconnection within ASEAN but also third-party electricity flowing through power grids all around ASEAN.

\section{Conclusion}

Using the framework of scenario analysis, this study identifies three possible scenarios of electricity market integration in ASEAN. The first scenario is Lao PDR-Thailand-Malaysia-Singapore (LTMS) interconnection. This is probably a relatively easy start-up of the eventual ASEAN Power Grid. Given the difficulty of getting Singapore involved in the LTMS arrangement, it may be easier to have the 'LTM' in place first. The second scenario is the interconnection of several heterogeneous power grids and markets. This is the most likely scenario to be achieved after the LTMS or the 'LTM' power trading is realized. Such a scenario will possibly take place in the GMS region, which has already had power trading on bilateral basis across countries in this region. The third scenario would be a competitive electricity market with a fully-developed APG, which requires high-level cooperation and trust among ASEAN countries. Under such a scenario, all electricity utilities will have unrestricted and nondiscriminatory grid access to the ASEAN electricity market.

This study examines how China's Belt and Road Initiative can facilitate electricity market integration under each scenario. It is found that Chinese companies can be most helpful under the first scenario and Chinese investments may bring new sources of funding and technology to facilitate the electricity market integration in the LTMS, or LTM countries, with more power plants built and more high voltage and ultra-high voltage power grids constructed and connected. Under the second scenario, given the existing power plants and power grids that they have built, Chinese companies can still be helpful in facilitating the interconnection of several heterogeneous grids in the GMS region. However, given the indistinctness of the progress of GMS electricity market integration, it remains to be seen that to what extent the Chinese investment can help electricity market integration in the region. Compared to the contribution the Chinese companies can do under the first scenario, their contribution is not quite clear under the second one. Under the third scenario, Chinese investment may play a less important role, because it seems that Chinese investment in ASEAN's power transmission is concentrated in the continental Southeast Asian region.

Further, given the characteristics of archipelago of maritime Southeast Asia, it is projected that there will only be limited power exchange in the near future. This may also deter Chinese companies from entering into this region. The third scenario is the most difficult arrangement for ASEAN to achieve and the least possible situation for BRI to play a role. Despite the difficulty, however, it is still possible for China to engage in the third scenario and facilitate the realization of APG. Yet this needs ASEAN as a whole to take collective action to make maritime Southeast Asia a region attractive to power sector investors. In any sense, how China's BRI can play a role in the ASEAN electricity market integration 
depends more on the host countries and on ASEAN rather than on the Chinese side. Against the BRI background, the ability for ASEAN countries to manage investments to finance high profile projects has become increasingly crucial. At present, ASEAN countries have tended to engage China on a bilateral level. In the future, ASEAN governments can collectively play a bigger role in attracting high quality projects from China. With a proactive approach, ASEAN countries can make the BRI a truly multilateral and sustainable initiative that promotes win-win cooperation, which can lead to a sustainable partnership between ASEAN and China. ASEAN and its member states should have their own plans as to how to make best use of China's BRI to encourage it to contribute to the region's electricity sector and electricity market integration. 


\section{References}

ACE. 2017b. ASEAN Energy Cooperation Report 2017. Jakarta: ASEAN Centre for Energy.

-. 2017a. "ASEAN Power Grid." ASEAN Centre for Energy. Accessed 18 April, 2018. http://www.aseanenergy.org/programme-area/apg/.

ADB. 2009. Building A Sustainable Energy Future: The Greater Mekong Subregion. Manila: Asian Development Bank.

ADB. 2018. The Ha Noi Action Plan 2018-2022. Manila: Asian Development Bank.

APAEC, 2004. ASEAN Plan of Actions for Energy Cooperation 2004-2009.

Amer, Muhammad, Tugrul U Daim, and Antonie Jetter. 2013. "A review of scenario planning." Futures 46: 23-40.

Andrews-Speed, Philip. 2011. Energy Market Integration in East Asia: A Regional Public Goods Approach. ERIA Discussion Paper Series, Jakarta: Economic Research Institute for ASEAN and East Asia.

-. 2016. "Energy Security and Energy Connectivity in the Context of ASEAN Energy Market Integration." Energy Security and Connectivity: The Nordic and European Union Approaches. Singapore: Energy Studies Institute, National University of Singapore, February.

Andrews-Speed, Philip, and Adnan Hezri. 2013. "Institutional and Governance Dimensions of AEMI." In ASEAN Energy Market Integration (AEMI): From Coordination to Integration, by AEMI Group, 149-173. Bangkok: ASEAN Studies Center, Chulalongkorn University.

Andrews-Speed, Philip, and Christopher Len. 2013. "The political economy of AEMI." In ASEAN Energy Market Integration (AEMI): From coordination to integration, by AEMI Group, 197214. Bangkok: ASEAN Studies Center, Chulalongkorn University.

Antikainen, J., Gebert, R., Moller, U., 2011. Review of the Greater Mekong SubRegion Regional Power Trade. Stockholm.

Bhattacharyay, Biswa Nath. 2009. Infrastructure Development for ASEAN Economic Integration. ADBI Working Paper 138, Tokyo: Asian Development Bank Institute.

BMI Research. 2017. BMI Research: Malaysia in world's top three for renewable energy investment. http://bradmanrecruitment.com/bmi-research-malaysia-worlds-top-three-renewableenergy-investment/.

Bredesen, Hans-Arild, and Terje Nilsen. 2013. Power to the People: The First 20 Years of Nordic Power-Market Integration. Oslo: Nord Pool Spot/Nasdaq OMX.

Chia, Jonathan, and Marilyn Ten. 2015. Sarawak needs more investments from China. http://www.theborneopost.com/2015/12/03/sarawak-needs-more-investments-fromchina/.

Chun, Sophal. 2009. "EdC signs electricity line deal with China." The Phnom Penh Post. September 4. Accessed June 8, 2017. http://www.phnompenhpost.com/business/edc-signs-electricityline-deal-china. 
Finenko, Anton, Anthony D Owen, and Jacqueline Tao. 2017. "Power Interconnection in the ASEAN Region: Lessons Learnt from International Experience." ESI Policy Brief. Singapore: Energy Studies Institute, March 10.

Fontela, E, and A Hingel. 1993. "Scenarios on economic and social cohesion in Europe." Futures 25: $139-154$.

GEIDCO. 2018. Research Report of Southeast Asian Energy Interconnection Planning. Beijing: Global Energy Interconnection Development and Cooperation Organization.

Georgoff, David M, and Robert G Murdick. 1986. "Manager's Guide to Forecasting." Harvard Business Review 110-120.

Halawa, E., James, G., Shi, X., Sari, N., Nepal, R., 2018. The Prospect for an Australian-Asian Power Grid: A Critical Appraisal. Energies. https://doi.org/10.3390/en11010200

Hart, Michael. 2018. "Myanmar's Ethnic Conflicts Have Multiple Fronts, and High Barriers to Peace." World Politics Review. 24 May. Accessed 19 June, 2019. https://www.worldpoliticsreview.com/articles/24782/myanmar-s-ethnic-conflicts-havemultiple-fronts-and-high-barriers-to-peace.

Heijden, Kees van der. 2005. Scenarios: The Art of Strategic Conversation, 2nd Edition. Chichester, England: Wiley.

Huss, William R. 1988. "A Move Toward Scenario Analysis." International Journal of Forecasting 4: 377-388.

IEA. 2015. Southeast Asia Energy Outlook 2015. World Energy Outlook Special Report, Paris: OECD/IEA.

IEA. 2017. Southeast Asia Energy Outlook 2017. World Energy Outlook Special Report, Paris: OECD/IEA.

Industrial Headlines. 2016. "President Xi and the Prime Minister Hun Sen are all concerned the Cambodian project (in Chinese)." Industrial Headlines (Gongye Toutiao). October 19. Accessed June 8, 2017. http://www.gongyetoutiao.com/xw/html/5526.shtml.

IRENA. 2017. Renewable Energy Outlook - Thailand. https://www.irena.org//media/Files/IRENA/Agency/Publication/2017/Nov/IRENA_Outlook_Thailand_2017.pdf.

Joergensen, B.H. 2016. "ASEAN ENERGY MARKET INTEGRATION (AEMI) Energy Security and Connectivity: The Nordic and European Union Approaches." ASEAN Studies Centre, ESI, NIAA.

Jones, Lee. 2016. "Explaining the failure of the ASEAN economic community: the primacy of domestic political economy,." The Pacific Review 647-670.

Kumar, Prem P. 2015. "Malaysia: ASEAN power grid needed to develop region." Anadolu Agency. 5 October. Accessed 13 April, 2018. https://aa.com.tr/en/economy/malaysia-asean-powergrid-needed-to-develop-region/431995.

Kunmakara, May. 2014. "China power plant open." The Phnom Penh Post. August 15. Accessed June 8, 2017. http://www.phnompenhpost.com/business/china-power-plant-open. 
Li, Y., Shi, X., Su, B., 2017. Economic, social and environmental impacts of fuel subsidies: A revisit of Malaysia. Energy Policy. https://doi.org/10.1016/j.enpol.2017.08.015

Lu, Guangsheng. 2016. China seeks to improve Mekong Sub-Regional Cooperation: Causes and Policies. Policy Report, Singapore: S. Rajaratnam School of International Studies.

Martino, J P. 2003. "A review of selected recent advances in technological forecasting." Technological Forecasting and Social Change 70: 719-733.

Mietzner, D, and G Reger. 2005. "Advantages and disadvantages of scenario approaches for strategic foresight." International Journal of Technology Intelligence and Planning 1: 220-239.

OECD/IEA. 2017. Southeast Asia Energy Outlook 2017. Paris: OECD/IEA.

Olchondra, Riza T. 2016. "NGCP aligns plan with Asean power interconnection vision." Philippine Daily Inquirer. 4 March. Accessed 13 April, 2018.

http://technology.inquirer.net/47042/ngcp-aligns-plan-with-asean-power-interconnectionvision.

Phomnuny, Petsamone. 2017. "Laos Expects to Have 100 Hydropower Plants by 2020." Lao News Agency. 6 July. Accessed 26 April, 2018. http://kpl.gov.la/En/Detail.aspx?id=25944.

Pim, Lim How. 2017. Borneo Online. http://www.theborneopost.com/2016/03/25/chinese-firminvests-rm1-bln-in-sama-jaya/.

Porter, Alan L, Scott W Cunningham, Jerry Banks, Thomas Roper, Thomas W Mason, and Frederick A Rossini. 2011. Forecasting and Management of Technology, 2nd Edition. New York: Wiley.

Sahid, Endang Jati Mat, Isa Mohd Aishah, Y P Leong, and Xunpeng Shi. 2013. "Rationale for AEMI." ASEAN Energy Market Integration (AEMI) Initiative. September. Accessed 19 April, 2018. http://www.asean-aemi.org/aemi-working-papers/.

Sharma, Deepak. 2005. "Electricity Reforms in the ASEAN: A Panoramic Discourse." Economic and Political Weekly 40 (50): 5318-5326.

Shi, X., 2014. ASEAN Power Grid, Trans-ASEAN Gas Pipeline and ASEAN Economic Community: Vision, Plan and the Reality. Glob. Rev. 2014, 116-131.

Shi, X., 2016. The future of ASEAN energy mix: A SWOT analysis. Renew. Sustain. Energy Rev. 53, 672-680. https://doi.org/10.1016/j.rser.2015.09.010

Shi, Xunpeng, and Cecilya Malik. 2013. Assessment of ASEAN Energy Cooperation within the ASEAN Economic Community. ERIA Discussion Paper Series, Jakarta: Economic Research Institute for ASEAN and East Asia.

Shi, X., Kimura, F., 2010. Energy market integration in the East Asia Summit region: Review of initiatives and estimation of benefits. ERIA Res. Proj. Rep. 2009 No. 13.

Shi, X., Kimura, F., 2013. The Status and Prospects of Energy Market Integration in East Asia, in: Wu, Y., KIMURA, F. (Eds.), Energy Market Integration in East Asia: Deepen Understanding and Move Forward. Rutledge, London, pp. 9-24.

Silitonga, Rio Jon Piter. 2018. "Trading Renewable Energy Through the ASEAN Power Grid." ASEAN Centre for Energy. August 7. Accessed December 17, 2018. 
http://www.aseanenergy.org/blog/trading-renewable-energy-through-the-asean-powergrid/.

Timperley, Jocelyn. 2018. "China Leading on World's Clean Energy Investment, Says Report." EcoWatch. January 10. Accessed July 4, 2018. https://www.ecowatch.com/china-cleanenergy-investment-2524206487.html.

van Notten, Philip W.F, Jan Rotmans, Marjolein B.A van Asselt, and Dale S Rothman. 2003. "An updated scenario typology." Futures 35 (5): 423-443.

Varum, C A, and C Melo. 2010. "Directions in scenario planning literature - A review of the past decades." Futures 42 (4): 355-369.

Vecchiato, Riccardo, and Claudio Roveda. 2010. "Strategic foresight in corporate organizations: Handling the effect and response uncertainty of technology and social drivers of change." Technological Forecasting and Social Change 77 (9): 1527-1539.

Wu, Y., Kimura, F., Shi, X., 2013. Energy Market Integration in East Asia, Energy Market Integration in East Asia: Deepening Understanding and Moving Forward. Routledge, London. https://doi.org/10.4324/9781315883205

Wu, Y., Shi, X., Kimura, F., 2012. Energy Market Integration in East Asia: Theories, Electricity Sector and Subsidies. ERIA Res. Proj. Rep. 2011, No. 17.

Xinhuanet. 2015. "Laos' northern 230 KV power grid put into operation." Xinhuanet. November 30. Accessed January 23, 2018. http://www.xinhuanet.com/english/201511/30/c_134866617.htm.

Zhang, Jianping, and Daojiong Zha. 2014. "Promoting energy market integration between China and the Association of Southeast Asian Nations through trade facilitation." In Energy Market Integration in East Asia: Deepening understanding and moving forward, edited by Yanrui Wu, Fukunari Kimura and Xunpeng Shi, 76-98. Oxon: Routledge and Economic Research Institute for ASEAN and East Asia. 